\title{
HELP FROM ABOVE
}

\author{
Air Force Close Air Support \\ of the Army
}

1946-1973

\author{
John Schlight
}

\section{AIR FORCE HISTORY AND MUSEUMS PROGRAM Washington, D. C. 2003}

\section{DEPOSITORY} APR 072004

UNIVERSITY OF ILLINOIS AT URBANA-CHAMPAIGA 